\title{
Research on the Internal Marketing of Human Resources Department Based on Perspective of Both Supply and Demand
}

\author{
Yuling Chen \\ Business School, Sichuan University \\ Sichuan University \\ Chengdu, Sichuan, P.R. China \\ e-mail:doudou_chenyl@163.com
}

\author{
Weizheng Chen* \\ Business School, Sichuan University \\ Sichuan University \\ Chengdu, Sichuan, P.R. China \\ e-mail: charleswchen@163.com \\ *: Corresponding author
}

\begin{abstract}
Internal marketing is an influential activity inside one organization. The internal marketing by human resources (HR) department is of great significance in promoting products and services and enhancing internal customers' satisfaction. This study has integrated marketing subject and object via the application of Business Model Canvas proposed by Osterwalder and Pigneur. By means of literature research and from the perspective of both supply and demand, it has analyzed how human resources department can take the initiative to meet internal customers' needs in order to achieve department value, and finally has constructed a theoretical model for the internal marketing of HR department and proposed some research prospects.
\end{abstract}

Keywords-perspective of both supply and demand; human resoruces department; internal marketing; Business Model Canvas; value of service

\section{INTRODUCTION}

The notion of internal marketing was firstly proposed by Berry in 1976. Berry[1] defined it as, "to regard staff as customers and work as products, and to achieve the organization's goals and meet internal customers' needs at the same time", and "with the work itself (products) to attract, develop, motivate and retain outstanding employees and meet their needs"[2]. The main work of HR department is to use scientific methods to select, hire, educate and retain employees. The value of its work will affect the realization of organizational strategies and objectives [3]. In order to achieve the goal of strategic HR management, whether HR department can be viewed as a "virtual service company"[4] by applying internal marketing concept, so as to enhance the work value of HR department and bettersatisfy the organization's needs?

\section{LITERATURE REVIEW}

\section{A. Internal Marketing}

The evolution of internal marketing concept has experienced three stages:

The first stage: the pursuit of employees' motivation and satisfaction. To achieve customers' satisfaction, the company must make the employees satisfied as well [5], especially in the service areas where the customers have higher expectations on employees. If these employees can work as a source of self-actualization and selfdevelopment, then they will show more courtesy and empathy in their contact with customers, thus making customers more satisfied [6]. However, in 1993, Rafiq and Ahmed[6] pointed out the following potential problems of internal marketing: (1) The "products" sold to employees may not meet their needs or even have a negative effect; (2) The employees are less likely to have the opportunity to choose "products"; (3) Due to the employment contract, employees may be forced to accept the "products" they don't need; (4) To meet staff's needs requires to consider the costs; (5) It may lead to the priority of external customers' needs over the staff's needs. These two scholars' questions on internal marketing have enlightened the author: internal marketing should provide customers with the products and services that they are really in need of, and consider the costs and conditions at the same time; Apart from meeting customers' dominant needs, it will be better to create demand for customers.

The second stage: customer-oriented consciousness. Gronroos [7] believes that internal marketing is designed to meet the needs of external customers. The interaction between employees and customers can not only affect the current and repeated purchase behaviors, but also provide market opportunities for the organization. Thus, employees need to have customer-oriented and sales consciousness.

The third stage: the promotion of strategic implementation and organizational transformation. Winter[8] proposes that internal marketing promotes the realization of organizational goals via allying with staff, educating and motivating them; George[9] suggests that internal marketing is a philosophy about organizational human resources, and it is also an overall management process with a set of multiple functions; Glassman and McAfee[10] emphasizes internal marketing plays a role in the integrated marketing and human resource management; Rafiq and Ahmed[6] puts the definition of internal marketing: it is through planned efforts to overcome the resistance to organizational transformation and through 
allying, motivating and uniting employees to achieve the strategies of company and functional departments.

\section{B. Researches on HR Internal Marketing}

Internal marketing is a philosophy of viewing staff as customers. The employees' satisfaction is not only conducive to bring out their potential, but also to achieve organizational goals. The training, motivation and career planning for staff by HR department are also to bring staff's enthusiasm and creativity into full play. The objectives of internal marketing have something in common with those of HR management. Relevant researches are as follows:

Internal marketing is the new perspective of HR management. An increasing number of companies require the HR managers with a higher level of competence and skills, while the marketing concepts and technologies can help upgrade the efficiency of HR managers, and their success can also assist other functional departments to improve their performance [3]. Harris and Ogbonna [11] have studied on the relationship among strategic HR management, marketing orientation and organizational performance. The result demonstrates that marketing orientation and organizational performance are directly related, while strategic HR management and organizational performance are indirectly related under the influence of marketing orientation. Bowen [12] holds that HR management has a positive impact on the satisfaction of internal and external customers, so the HR department should make the front-line employees satisfied, and then they can provide better motivation and services to external customers. Gounaris [13] has researched on the relationship between internal marketing orientation and employees' job satisfaction by interviewing with managers and staff from 20 five-star hotels. The result shows job satisfaction is directly related to internal marketing, while the internal marketing orientation plays a regulative role between internal marketing and job satisfaction.

Domestic scholars' researches are as follows. Hu Shaoying and Li Jianliang [14] believe that HR department should establish the concept of "green marketing". In other words, according to the internal and external environ ment of the enterprise and different internal demands of employees, it is to supply differentiated human resource services and products to the three types of employees: material oriented, career oriented and relationship oriented. Dong Xueqin [15], based on the internal customers' different levels by HR department, divides internal customers into CEO, line managers and ordinary employees, and also puts forward marketing strategies for different customers. Li Xinjian, et al. [16] have mentioned that, the value of HR department is rising continuously in theory, but its role in practice is difficult to be recognized. The problem may lie in the mode selection of HR management to earn value for organization. The traditional HR management is mostly oriented at "product-supply" and ignores the customers' real needs, while the management concept of internal marketing is a model of customer-oriented. Li Kefang [17] has constructed an integrated model of internal marketing and $H R$ management. She points out that through market research and segmentation, and the combination of internal marketing and the recruitment, training and incentive process of human resources, this model would meet the needs of employees and ultimately enhance the competitiveness of enterprises. Tan Lingbo et al. [18] have studied the issue marketing process and strategies of HR managers. This article divides the issue marketing process into many phases, such as perception, selection, proposing, brewing, packaging and presenting, and puts forward issue marketing strategies, which contributes to promoting the influence of HR department within the organization. Lei Shuiqing [19] has probed into the application of internal marketing theory in the HR management in universities. The paper analyzes universities' characteristics in providing services and proposes to supply different customers with different "products", like salary, job autonomy, supportive work environment and learning opportunities. In addition, some scholars have studied the human resources recruitment marketing [20] [21], indicating the application of $4 \mathrm{P}$ and $4 \mathrm{C}$ models in marketing to promote company's positions to job seekers. Its marketing object is external customers that are beyond the scope of present study.

In summary, previous researches are either from the quantitative point of view to study the correlation between internal marketing and HR management, or from the qualitative point of view to expound strategies in the realization of human resources internal marketing. Regarding to the internal marketing strategies, most scholars are from customers' perspective to advocate market investigation and segmentation and provide customers with differentiated services; some also start from the service provider by applying $4 \mathrm{P}$ marketing model to analyze products, pricing, channel and promotion strategies; but few scholars have conducted in-depth research on the internal marketing strategy of HR department from the perspective of both marketing subject and object. Taking the interests of both provider and user of certain products or services into account will be more conducive to arouse enthusiasm of both sides. Li Xiyuan [4] also believes that to carry out human resource internal marketing can make the work value of human resources to be fully reflected. He has cited the case that in 1998 TSMC human resources transformed from traditional administrative personnel into strategic human resources. $\mathrm{He}$ points out that the company has positioned its HR department as a virtual company, and with this business philosophy the company can "produce" HR products to better meet staff's needs. The case opens up a new way for this research: if HR department can position itself in the company's management level, thinking and decisionmaking as a company, then is its internal marketing more likely to achieve a win-win situation between customers and HR department itself?

\section{INTERNAL MARKETING MODEL OF HR DEPARTMENT}

As is mentioned above, if HR department is positioned as a virtual company in operation, then the products and services supplied by HR department will cater to customers' needs, thus realizing the department value or even increasing its value. Then can the business models of a company be learnt or applied into the business of its departments? Although each company's business model is different from that of others, there are also some 
similarities. Osterwalder and Pigneur [22] [23], in their Business Model Generation, put that the business model is a basic principle of the enterprise to create value, deliver value and acquire value. They have found some similarities in management and summarized them as the common language of business model, as is shown in the following table:

TABLE I. Business Model CANVAS

\begin{tabular}{|c|c|c|c|c|}
\hline $\begin{array}{l}\text { Import- } \\
\text { ant } \\
\text { cooper } \\
\text { ation: }\end{array}$ & $\begin{array}{c}\text { Key } \\
\text { business } \\
\text { : } \\
\text { What do } \\
\text { I need to } \\
\text { do }\end{array}$ & \multirow[t]{2}{*}{$\begin{array}{c}\text { Value of } \\
\text { service: } \\
\text { How can } \\
\text { I help } \\
\text { others }\end{array}$} & $\begin{array}{l}\text { Customer } \\
\text { relationsh } \\
\text { ip: } \\
\text { How to get } \\
\text { along with } \\
\text { each other }\end{array}$ & $\begin{array}{c}\text { Custo } \\
\text { mer } \\
\text { segmen } \\
\text { tation: } \\
\text { Whom } \\
\text { I can }\end{array}$ \\
\hline $\begin{array}{l}\text { Who } \\
\text { can } \\
\text { help } \\
\text { me }\end{array}$ & $\begin{array}{c}\text { Core } \\
\text { resource } \\
\text { s: } \\
\text { Who am } \\
\text { I, and } \\
\text { what do } \\
\text { I possess }\end{array}$ & & $\begin{array}{c}\text { Access } \\
\text { channel: } \\
\text { How to } \\
\text { promote } \\
\text { ourselves } \\
\text { and } \\
\text { delivery } \\
\text { service }\end{array}$ & $\begin{array}{l}\text { Whom } \\
\text { I can } \\
\text { help }\end{array}$ \\
\hline \multicolumn{3}{|c|}{$\begin{array}{c}\text { Cost structure: } \\
\text { What do I need to pay }\end{array}$} & \multicolumn{2}{|c|}{$\begin{array}{c}\text { Source of income: } \\
\text { What can I get }\end{array}$} \\
\hline
\end{tabular}

Data source: Osterwalder and Pigneur [22] [23]

Fro $m$ the table, it can be seen, Business Model Canvas considers not only the case of one's own, including "important cooperation", "key business" and "core resources", but also the situation of the other side, like "customer relationship", "access channel" and "customer segmentation"; "value of service" is the matching result between both sides of supply and demand; the awareness of "cost structure" and "source of income" should always be kept through the whole process of management, and HR department should be reminded to consider the costs and benefits of itself as well as its customers. To apply this tool in HR internal marketing can help HR managers to clarify their ideas, not only in the major issues of marketing, but also in its daily routines. So, how can Business Model Canvas be applied in the analysis of internal marketing in HR department, and then succeed in "managing" this department?

"Important cooperation": it refers to the partner of HR department, namely "who can help me". Inside a company, HR department is in contact with almost all the functional departments of the company, and these departments are the customers and also important partners of HR department. Besides, HR department's important partners also include corporate executives. According to the theory of Leadermember Exchange (LMX), leader's time and energy are scarce, so the leader will have a close relationship with only a small portion of his subordinates, and give them more attention, support and trust. These subordinates are called "insiders". While the other subordinates are named as "outsiders", for they take up less of the leader's time and receive less support and attention [24]. Therefore, HR managers need internal marketing to obtain more support and resources from executives.

"Key business": it is the most important things that the department has to do for its survival, that is, "what do I need to do". The basic task of HR management is to attract, retain, motivate and develop human resources that the organization needs, and to promote the achievement of organizational objectives, so that the organization can survive and develop in the fierce market competition [25]. Specifically, HR management includes six major categories of work: hu man resources planning, recruit ment and configuration, training and development, performance management, compensation management and labor relations management. The work of HR department should focus on these aspects, but it does not mean that the above work should be done by HR department itself. According to the view of modern management, enterprise managers at all levels are HR managers, and they are the executors of HR management, while the HR department serves as a role to provide guidance and advice [25]. Furthermore, the HR department should become an important partner of business sector (HRBP), providing important information and decision recommendation.

"Core resources" refers to the most important factors which are essential for a sector's effective functioning, namely, "what do I possess". Talents are the most important resource owned by HR department. Staff in HR department must first have certain professional knowledge and skills. In addition to human resources related knowledge, it's better for them to acquire some other relevant expertise. For example, legal knowledge would enable them to be familiar with the relevant provisions of labor law, contract law and company law; financial knowledge helps them learn how to account and audit costs in HR management; knowledge of psychological counseling can be useful to adjust their mentality when some employees are in confusion or at a loss. Apart from relevant knowledge and skills, these staff's personal traits, like interests, personalities and values, are also the core resources of HR department. Particularly, if their personal traits are well-matched with the job requirements and content, then their job satisfaction and organizational performance will be highly promoted.

The three parts above are the resources and major responsibilities of HR department, and these are the process of "knowing one's own case". The following will analyze the parts of "knowing the opposite side".

"Customer segmentation" indicates the division of customers according to different criteria in order to provide more targeted products and services. HR department is at the interests intersection of multi-stakeholder and difficult to accumulate evidence to prove its own value [18]. Thus, the internal customers' segmentation can improve the quality of service, but also upgrade the value of HR department in the company. Internal customers under HR department are layered as CEO, line managers and ordinary employees based on the hierarchy [4] [15]; and they can also be offered with differentiated services according to their years of service in the company, such as the guidance of socialization for new employees, career planning for senior staff, communicating with employees who intend to leave office on their motives and reasons for leaving, and so forth.

"Customer relationship": according to the interpretation from Osterwalder and Pigneur [23], it is how to establish relationships with customers, including communication mode (direct or indirect communication) 
and service mode (one-time or continuous service). HR department communicates with its internal customers mostly in a direct way. This mode of communication can lead to in-depth exchanges, thus knowing the customers' problems, difficulties and causes, and being aware of their emotions and feelings. While, convenient as indirect communication is, it is difficult to ensure the communication quality. HR staff is required to have good communication skills and pay attention to the communication mode, especially when the staff's interests are involved. Generally the services of HR department are continuous, so timely tracking and feedback should be emphasized before, during and after a certain is sue.

"Access channel" is a way to promote and deliver services. HR department can advertise and promote its products and services through direct preaching, interviewing with key customers, or by telephone or mail. It can also utilize printed promotional materials and leaflets, and even take effective measures to write them into company's internal constitutions and provisions. The delivery services of HR department are reflected in specific work, and with the development of $H R$ management, virtual services are also available.

Business Model Canvas is a systematic and comprehensive tool, which enables HR department to know itself as well as its opposite side, thus contributing to better internal marketing. However, there are also areas in need of improvement: the description of "customer relationship" overlaps with that of "access channel". For instance, communication skills are crucial not only in the maintenance of good relations with internal customers, but also in the promotion of own products, so there is no need to separate the two but to put both under "access channel". Besides, "customer segmentation" is intended to better meet the needs of different customers, but the canvas does not contain the item of "customer demand", and this study will add it. Furthermore, apart from the understanding of itself as well as its internal customers, HR department should also follow the company's strategy, and adapt to its development stage, scale and nature. Otherwise, the products and services provided will be difficult to promote. Based on these supplements, this research has divided the business model of HR department into three aspects: understand itself, understand customer and understand company, as is shown in the following figure.

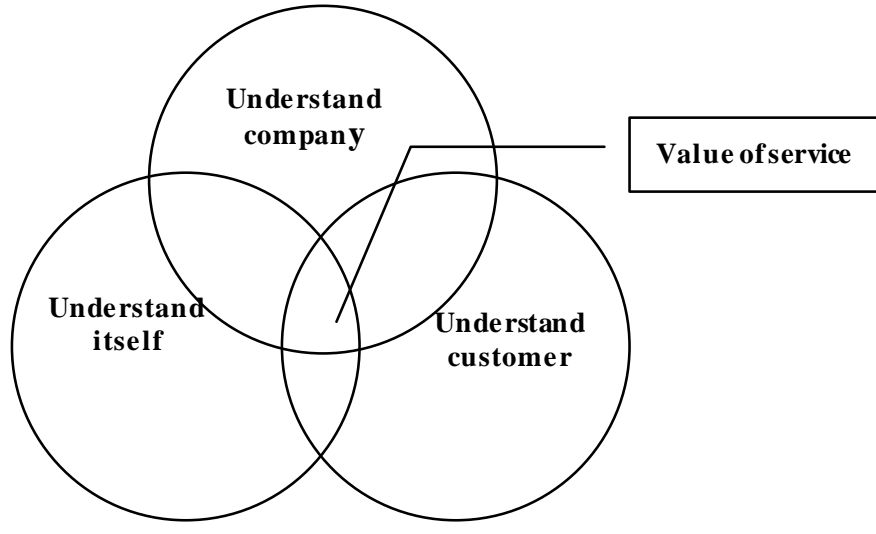

Figure 1. Business Model of HR Department
Seen from the figure above, the intersection of the three is the "value" of products or services provided by HR department. The value can be mirrored from the improved customers' work efficiency, the reduced costs, or the increased customer's psychological capital, etc.. If HR department can establish a "product supermarket" by combining its own "core resources" and present its services in the form of a menu or a module, then the customers would select services actively, and the services' level and quality would be highly promoted. For example, HR managers who are qualified psychological consultants can provide group psychological counseling for employees; those with special literary talent can organize some interests groups in the company; and those interested in reading can hold a variety of colorful reading sessions.

Then how can the work value of HR department be accurately measured? According to the research on value engineering, it can be represented by an equation: $\mathrm{V}=\mathrm{F} / \mathrm{C}$. $\mathrm{V}$ is value, $\mathrm{F}$ represents function, and $\mathrm{C}$ is cost. If it intends to promote the value of its products or services, then it needs to either increase the functions or reduce the costs, and the ratio of increased functions should be greater than that of reduced costs [26]. Based on the above analysis, this paper proposes the following internal marketing theory model of HR department:

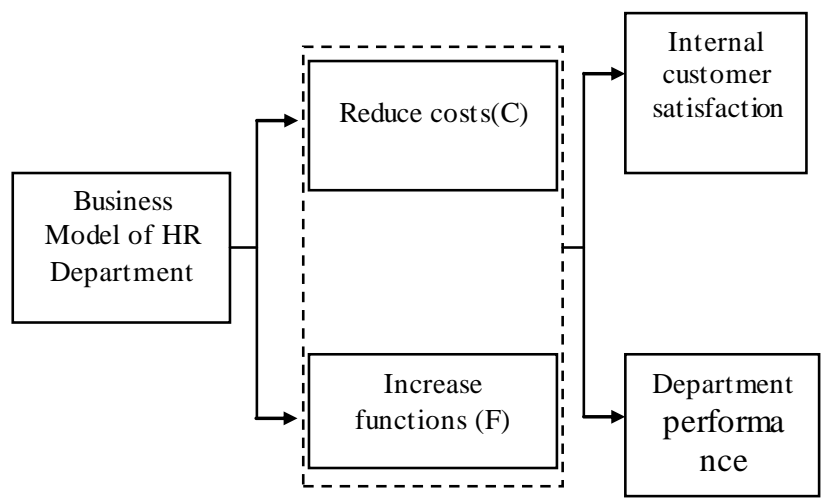

Figure 2. Internal Marketing Theory Model of HR Department

The model suggests that HR department should have systematic thoughts for successful management, and it is also essential to integrate the consideration on the department itself, its internal customers and company so as to supply products and services of higher quality. Its work value is mainly reflected in reduced costs and increased functions, and the value may ultimately have a positive impact on the internal customers' satisfaction and the HR department's performance. Whether the relationship between these variables is consistent with that presented in above theoretical model or not? This will be studied in the following empirical research.

\section{RESEARCH PROSPECTS}

This research has positioned human resources department as a virtual company. It has illustrated the internal marketing of HR department from the perspective of both supply and demand and the company's situation. Compared with the traditional marketing of HR department, internal marketing does not require its internal customers to pay directly for the products or services provided by HR department. Due to the need of labor 
division, the products and services provided by all the functional departments, including HR department, are irreplaceable and lack of competition. Therefore, it is particularly significant to stimu late HR department to take the initiative to meet and create demands for internal customers. The follow-up study will employ questionnaire survey and in-depth interviews to verify the validity and rationality of the above theoretical model. In addition, if the value engineering method is used to measure the work value of HR department, then what are the specific measures? Whether the internal marketing model of HR department can be copied to other functional departments? Does this have any constructive meaning for building service-oriented government? These issues will be explored and studied in depth in the following research.

\section{ACKNOWLEDGMENT}

We sincerely appreciate for the support on this project from the National Natural Science Fund Project "An Empirical Research on the Influence Factors, Formation Mechanism and Intervention Strategies of Enterprise Employees' Sense of Work Alienation" (project approval number: 71272210, Responsible Person: Chen Weizheng).

\section{REFERENCES}

[1] Berry L L. The employee as customer [J]. Journal of Retail Banking. 1981 (3): 33-40.

[2] Mohammed Rafiq, Pervaiz K Ahmed. Advances in the internal marketing concept: definition, synthesis and extension [J]. Journal of Services marketing. 2000, 14(6): 449-462.

[3] Collins Brett, Adrian Payne. Internal market ing: a new perspective for HRM [J].European Management Journal. 1991, 9 (3) : 261-270.

[4] Li Xiyuan. Internal marketing and human resources management[J]. Jianghan Forum. 2004 (10): 60-62.

[5] George W R. The retailing of services-a challenging future [J]. Journal of Retailing. 1977, 53 (3): 85-98.

[6] Mohammed Rafiq, Pervaiz K Ahmed. The scope of internal marketing: defining the boundary between marketing and human resource management [J]. Journal of Marketing. 1993, 9 (3): 219232.

[7] Gronroos C. Internal marketing - an integral part of marketing theory[J]. Marketing of Services. 1981: 238-238.

[8] Winter J P. Getting your house in order with internal marketing: a marketing prerequisite [J]. Health Marketing Quarterly. 1985, 3 (1): 69-77.

[9] [9]George W R. Internal marketing and organizational behavior: a partnership in developing customer-conscious employees at every level [J]. Journal of Business Research. 1990, 20 (1): 63-70.
[10] Glassman M, McAfee B. Integrating the personnel and marketing functions [J]. Business Horizons. 1992, 35 (3):52-59.

[11] Lloyd C Harris, Emmanuel Ogbonna. Strategic human resource management, market orient ation, and organizational performance [J]. Journal of Business Research. 2001,51 (2): 157-166.

[12] David E Bowen. Market-focused HRM in service organizations: satisfying internal and external customers[J]. Journal of Marketfocused Management. 1996, 1 (1): 31-47.

[13] Spiros Gounaris. The notion of internal market orientation and employee job satisfaction: some preliminary evidence $[\mathrm{J}]$. Journal of Services Marketing. 2008, 22 (1): 68-90.

[14] Hu Shaoying, Li Jianliang. "Green Marketing" management: a new concept of human resources management [J]. Theoretical Exploration. 2005 (4): 88-93.

[15] Dong Xueqin. On the application of enterprise's internal marketing to human resources management -- human resources market ing [J]. Weekly Market Research. 2005 (6): 114-116.

[16] Li Xinjian, Liu Zhao, Fu Meiyun. Exploration on the function model of customer-oriented human resources management [J]. Human Resources Development of China. 2009 (5):97-104.

[17] Li Kefang. Integrated model of internal marketing and human resources management[J]. Journal of Yunnan University of Finance and Economics. 2011 (6):112-118.

[18] Tan Lingbo, Xie Jinyu, Chen Yang. Research on the issue marketing process and strategies of human resources managers [J]. Management World. 2013(2): 141-155.

[19] Lei Shuiqing. Application of internal marketing theory in the human resources management in Universities [J]. Journal of Chengdu University (SOCIAL SCIENCE). 2006 (1): 91-93.

[20] Li Yi, Chen Jian. Target marketing concept in human resources recruitment [J]. The Economist. 2005 (7): 130-131.

[21] Gao Feng. Research on the recruitment of human resources marketing [J]. Journal of Qinghai Normal University (PHILOSOPHY AND SOCIAL SCIENCES). 2006 (1): 16-18

[22] [Switzerland] Alexander Osterwalder, [Belgium] Eve Pinio. Business model generation [M]. Tran. by Wang Shuai, Mao Xinyu and Yan Wei. Beijing: Mechanical Industry Press, 2011.

[23] [US] Tim Clark, [Switzerland] Alexander Osterwalder, [Belgium] EvePinio. Business model generation -- personal papers [M]. Tran. by Bi Chongyi. Beijing: Mechanical Industry Press, 2012.

[24] Chen Weizheng, Yu Kaicheng, Huang Peilun. Advanced tutorial on organizational behavior [M]. Beijing: Higher Education Press, 2004.

[25] Chen Weizheng, Yu Kaicheng, Cheng Wenwen. Advanced tutorial on human resources management and development [M]. Beijing: Higher Education Press, 2004.

[26] Yang Jianhao, Jin Lishun. Extended value engineering[M]. Beijing: National Defense Industry Press, 2009. 